\title{
The Development of Corporations and Corporate Law in the World and Russia throughout History
}

\author{
Marat R. Suleymanov ${ }^{1}$,Guzel A. Valeeva ${ }^{2}$ \\ ${ }^{1,2}$ Kazan Federal University, Post Graduate Student of the Law Faculty, ${ }^{2} \mathrm{Ph} . \mathrm{D} ., \mathrm{Kazan}$ Federal University, \\ Email: yasulmar@yandex.ru, Contact: +7 (917) -277-35-45., valeeva@icloud.com, Contact: +7 (903) -305-44-86.
}

Received: $21^{\text {st }}$ October 2017 Accepted: $16^{\text {th }}$ November 2017, Published: $31^{\text {st }}$ December 2017

\begin{abstract}
The modern world is characterized by the fact that the turnover and investment activity of business entities increase in order to meet the needs of the growing population of the world. The role of international civil society institutions and international organizations become more and more important in solving global problems so as environmental degradation, terrorism, armed conflicts, and natural disasters. All this leads to the emergence of new subjects, which somehow fall under the rules of international law, in connection with which the subject matter of international law continues to expand.

This paper deals with the origin of the legal entities (corporations) institution, the stages of its development and their specific features, and the specific features of its development in Russia. The following methods were used to perform the above tasks: the analysis, synthesis, comparative method, comparatively-legal method, the dialectic methods and some other methods due to the area of research. The results of the work can be effectively used in the future both in scientific research and in the development of teaching aids and methodological programs in international law.
\end{abstract}

Keywords: Transnational Corporations, Multinational Corporations, Globalization, Legal Entity, Private Law

\section{Introduction}

Over the past four decades, a rapid growth in crossborder business has been observed in the globalization conditions in the world. According to experts, approximately 100,000 transnational corporations (TNCs) produce about $25 \%$ of world GDP, and the financial turnover of such companies exceeds the budgets of some modern states. The private sector has become a significant economic and social force and is rapidly invading those sectors of the economy that were traditionally governed by the state, so transnational corporations begin to fulfill quasi-state functions.

In spite of the foregoing, the phenomenon of transnational corporations still has some uncertainty and instability. So, up to now, even a single term has not even been elaborated to refer to corporations of this kind. In different sources, one can meet the categories of multinational corporations, cross-border associations, international economic associations and others, but none of them is generally accepted. This shows that both in the doctrine and in the rulemaking there have not been a uniform approach to the consideration of the phenomenon of transnational corporations.

The following methods were used for the study: analysis, synthesis, comparative method, comparativelegal method, dialectic methods and some other methods determined by the field of research. The results of the research can be effectively used in the future both in scientific research and in the development of teaching aids and methodological programs in international law.

\section{Methods}

The concept of "corporation" is formed from the Latin words "corpus", "corpora", which means "body", "one whole". These concepts were put into use by the ancient Romans to designate a group of people who are legitimate in public life to act as a single entity or as an individual.

Initially, these terms arose within the system of Stoicism philosophy, according to which individual objects form a single entity, corpus, corpora, when they are united by one spirit, an idea. Corpora could be of three different types:

1) Homogeneous bodies (man, stone, tree, etc.);

2) Tangible composite bodies consisting of indissolubly connected homogeneous bodies (house, chariot);

3) Intangible composite bodies, which consist of homogeneous bodies, but are united by a single spirit (legion of soldiers, flock of sheep, crowd in the market) [1].

Already the early codified source of Roman law, Laws of the Twelve Tables, contained references to collegias odalicia, private corporations of a religious nature or associations based on a professional characteristic.

According to the Laws of the Twelve Tables, the inhabitants of Ancient Rome possessed almost complete freedom of formation of various associations. Such unions could be created by a minimum of three citizens (tres faciunt collegium) without special sanction or permission from the state; the main requirement for their activities was the requirement to observe the standards of public law in their activities. This order was borrowed by the Romans from Ancient Greece and existed until the end of the Republican period. 
In the I century B.C., according to the statute of the collegia (lex julia de collegus) of the Emperor August, the activities of corporations in Ancient Rome were made dependent on the availability of permission from the Senate. In the Republican period, it was considered that an organization cannot have property, since it was attached to the personalities of the participants of the organization and was distributed between them when the corporation ceased operations. Corporations did not act in the civil process on their own behalf.

There were three main types of such associations: societas (from Latin "partnerships"), societas publicanorum or publicani (public partnerships) and peculium (special societies).

Societas were a union of citizens to achieve certain goals which could lie both in the sphere of personal non-property and property relations. They provided financial services (argentarius), maritime transport (exercitor), conducted trade of food (frumentum), slaves (mancipium), clothing (sagaria). It is important to note that in the composition of societas, as a rule, there were several participants, usually two [2].

Societaspublicanorum or publicani were a late type of societas that had the right to carry out state contracts for tenders: the collection of taxes (vectigalia), the lease of mines and quarries for the extraction of minerals (aurum), the erection of infrastructure such as temples (templum), aqueducts (aqua), roads (via), supplies for the army and producing weapons (exercitus), and others. The number of publicani participants was also insignificant. According to many references to them in the historical sources on law, the largest number of members participated in them were nineteen people [3].

Peculium (special societies) were formed by slaves and other persons who were under the rule of paterfamilias (heads of the family). Speaking of the peculium, two important aspects should be noted: peculium could be granted to those who were under the control of a family, and it granted to these subjects a certain degree of freedom and autonomy; and those who had power over the subjects, peculium saved from additional risks in civil circulation.

It should be noted that the vast majority of ancient Roman corporations served public purposes or performed religious functions, which were usually performed by the state. Initially, such organizations were denoted by the Latin concepts collegium, corpus, but later they were called publicani (from the Latin publiccani - tax, state property). They may arise as the union of organizations which uniting their resources in order to successfully operate in the civil circulation.

The Code of Justinian (first half of the 6th century A.D.) established two groups of legal entities-unions: universitates personarum and universitates rerum.

Universitates personarum included the organizations participating in the civil turnover, which performed economic functions. Universitates rerum included the legal entities in which there was no membership; they had independent incomes and performed public functions (almshouses, orphanages, charity houses, hospitals) [4].

Since the beginning of the Middle Ages, the Christian church, independent cities, trade and artisan guilds, and charitable organizations have become the largest and most influential corporations.

The joint-stock companies had a significant impact on the highest levels of power. The English queen and the nobility invested huge sums in the British East Indian company.

Corporations of Europe and America gradually developed, more and more property was concentrated in their hands. The phenomenon when joint-stock companies expanded their influence to unprecedented scale, and individual shareholders had less and less possibility to influence the process of enterprise management, became the name of democracy of capitalism, and then of managerial capitalism. Approximately at the same time, a contract theory of the firm arose, which is sometimes also called the nexus of contracts theory. It consists in the fact that according to it, a corporation is not a single whole from the point of view of law, but a lot of different elements, as well as many contracts: contracts between shareholders, council members, managers, employees, suppliers, buyers, etc. Some proponents of this theory believed that shareholders do not own a corporation, because the corporation's property is scattered.

In Russia, the development of corporations and corporate legislation occurred with some delay compared to the countries of Western Europe and the United States. The first proto-corporations in Russia were shop guilds and merchant guilds having their own internal hierarchy, the system of production and marketing of products.

Code of the laws of the XI century, "Russian Truth", provided for a partnership agreement (pooling) concluded between merchants who were entitled to borrow money for trade.

Separately, we should note the role of Novgorod in the formation of the first Russian corporate associations. This large north-western city of Rus had many features of free European cities: there existed a special form of government - a boyar republic, for a long time the power of the prince did not spread to it.The citizens of Novgorod were freedom-loving and actively traded with European countries. The largest association of Novgorod merchants of XII-XIII centuries was the guild of wax traders "Ivanovo Sto" ("Ivanov's hundred"). Its purpose was to protect commercial interests, and regulate relations between the customers. This guild was a closed corporation with its own statute; it had its own reserve fund to cover expenses. At the same time, "Ivanovo Sto" performed its activities under the patronage of the local church. The disputable issues of the corporation were decided by the commercial court [5].

When in 1484 Novgorod was annexed to Moscow Russia, it dealt a severe blow to the Hanseatic Trade Union, which large representation was then in Novgorod. 
In 1550, Ivan the Terrible adopts the Code of Law which provided for certain privileges for large foreign wholesalers [6].

In 1722, Peter I issued a decree according to which a guild arrangement for handicraft production was introduced in the Russian Empire. In accordance with the rules of the Chief Magistrate in each city, merchants and artisans were divided into guilds and workshops. Also, the first Russian emperor in 1699 issued a decree according to which Russian merchants should unite their capital and form companies to engage in trade.

It should be noted that if in Europe the shops appeared due to the weakening of the central power, then in Russia shops finally took their shape under absolutism. In addition, the shops in Russia began to develop in parallel with the manufactories.

Manifesto of Catherine II of 1775 divided the merchant class into three guilds, depending on the size of the economic turnover of merchants.

Since the 16th century, the Moscow Trading Company, established by English merchants, began to operate in Russia. The aforementioned tsar Ivan the Terrible, with his letters of 1555 and 1567, granted the English merchants the right to freely trade on the territory of Russia, which, however, later would be limited. Also after some time there were Dutch and French companies engaged in fishing in Russia.

In order to protect domestic entrepreneurs, Tsar Alexei Mikhailovich ordered the development of the Novotorgovy Statute of 1667, which was designed in the spirit of a policy of protectionism and provided for high duties on the import of goods [7].

In 1723, the regulations of manufactories-collegiums were issued, under which companies received many privileges: the right to monopoly trade in certain types of goods, the right to receive subsidies, the right to be subject to a special court.

In the 18th century, two main forms of collective enterprises were formed in the Russian Empire: a jointstock company and a trading house. The latter was a kind of combination of Western and domestic models. In the Code of Laws of the Russian Empire four forms of trade and industry associations were envisaged: a full partnership, a limited partnership, a joint-stock company, and an arty partnership. Until 1917, it was the full and limited partnerships that were the main forms of consolidation of merchant capitals. G.F. Shershenevich gave the following definition of a general partnership: "Contractual union of persons for the production of commercial trade by joint funds on the basis of unlimited and joint responsibility of all participants". Further, the scientist gave the definition of another form of partnership: "In a limited partnership, along with general partners, those who responded indefinitely and participated directly in the management of the affairs of the partnership, there were depositors who were acting limitedly and did not participate in the management of the enterprise. The role of the depositor not only legally, but in fact was reduced to the role of a capitalist who trusted another person with his capital and escaped from direct participation in fact"[8].

It is curious that the history of domestic cooperation is closely linked with the movement of the Decembrists. After the Russian noblemen-revolutionaries were exiled to Siberia in 1825, they founded there the "Big Artel", which acted in accordance with its own charter, on the conditions of self-government, the availability of elected bodies, and share contributions. At the same time, consumer, credit, production and trade-andpurchasing cooperatives began to appear only after the abolition of serfdom in 1961 [9].

The revolution of 1917 significantly changed both the civil law system and the understanding and perception of the institution of legal persons in Russia. The emergence of the first socialist state led to the transformation of social relations, which consisted in the denial of private legal relations, the nationalization of all material resources, including economic societies. So on December 14, 1917, the All-Russian Central Executive Committee issued a decree according to which the banks were nationalized under the supremacy of the State Bank. On June 28, 1918 the Council of People's Commissars began to nationalize large-scale industry.

With the transition to a new economic policy, the Civil Code of the RSFSR (Russian Soviet Federated Socialistic Republic) of 1922 was adopted, which became the first codified normative legal act of private law in the history of Russia and envisaged four forms of associations: a full partnership (Article295 of the Civil Code), trust partnership (Article312 the Civil Code), limited partnership (Article318 the Civil Code) and the joint-stock company (Article322 the Civil Code).Citizens were allowed to enter into all kinds of contracts not prohibited by law.

However, the main reason for the state legalization of joint-stock companies in the RSFSR in the early 1920s was not the desire to introduce private capital into civil circulation, but consolidation of capital under the supervision of the government, which could then be used by the socialist state for its own purposes in the construction of a new society. So, according to the definition of Article364 of the Civil Code of the RSFSR, the Soviet government could have terminated the activities of a joint-stock company "in the event of its evasion from the goal specified in the statute, as well as in case of its deviation in the direction contrary to the interests of the state".

In accordance with the Decree of the Central Executive Committee and the Council of People's Commissars of the USSR of May 28, 1926, state enterprises were created that have been "joint-stock companies, which shareholders, according to their charter, could only be state and cooperative institutions and enterprises...".

\section{Summary}

Thus, the joint-stock organizational and legal form of economic associations in the USSR will subsequently become a form of organizing state industry and subordinating private capital to the state. By the 30th 
years of the 20th century, almost all joint-stock companies had ceased to exist, and state enterprises arose in their place. The foundations of the civil legislation of the USSR and the Union republics in 1961 no longer contained the norms on joint-stock companies, and the Civil Code of the RSFSR in 1964 completely excluded economic partnerships and societies from civil legal relations.

In the 1970s, production associations which were not legal entities have been formed in the USSR. They managed and rationalized the activities of their enterprises, what brings production associations closer to modern holdings and financial-industrial groups.

The next round of changes occurred only during the period of perestroika. So in 1987, the USSR Council of Ministers issued a decree on the procedure for the establishment of joint ventures with the participation of Soviet organizations and firms of capitalist and developing countries on the territory of the USSR and the activities of joint ventures. In the same year, the USSR Law "On the State Enterprise" was adopted which, despite many innovations regarding the organizations' ability to unite in different structures, had many gaps. For example, the legal status and legal basis of such structures were not established.

On May 26, 1988 a rapid development of the non-state sector of the economy began in our homeland, caused by the adoption of the USSR Law "On Cooperation in the USSR". It allowed citizens to create cooperatives for engaging in any non-prohibited activities, including foreign trade [10]. In the aftermath of the reform of the 1990 s, the functioning of cooperative organizations was damaged.

With Regulations on joint-stock companies and limited liability companies approved by the USSR Council of Ministers on June 19, 1990, the registration system for the creation of joint-stock companies was approved for the first time in the Russian (Soviet) legislation. The law of the RSFSR "On Enterprises and Entrepreneurship" dated December 25, 1990 contained an inventory of organizational and legal forms of enterprises, in the same year the Council of Ministers of the RSFSR approved the "Regulations on Joint Stock Companies" which provided for the creation of joint stock companies of an open type and a closed type.

Further, many legal inaccuracies and inconsistencies were corrected by the Civil Code of the Russian Federation of 1994, in which the list and concept of economic partnerships and business entities were defined. The Code does not contain definitions of the concept of "corporation", but it provides for the following forms of commercial corporate organizations in Russia: full and trust partnerships, farm enterprises, limited liability companies, joint-stock companies and production cooperatives.

\section{Conclusion}

Thus, in their development, corporations have come a long way before adopting a transboundary form, although in the Middle Ages there were trade enterprises that opened branches in other countries (for example, the Hanseatic Union mentioned by us had offices in several European cities, including also in Novgorod). However, it was only in the twentieth century that the activities of corporations gained unprecedented scope, which significantly complicated the possibility of regulating their activities.

\section{Acknowledgements}

The work is carried out according to the Russian Government Program of Competitive Growth of Kazan Federal University.

\section{References}

1.Berle, Adolf A. and Gardiner C. Means (1932). The Modern Corporation and Private Property, New York: MacMillan.

2.Bartocek M. Roman law: concepts, terms, definitions. M., 1989, pp. 44 - 45.

3.Schreuer C. Investments, International

Protection. - Oxford: Max Planck Encyclopedia of Public International Law, 2011. - 114 p.

4.Muchlinski P.T. Multinational Enterprises and the Law (2nd edition). - London: OUP, 2017. - 74 p.

5.Martyshin O. V. Free Novgorod: Social and political system and law. -M. , 2014.

6.Andreev A.I. The Novotorgovy Statute of 1667// Historical notes. 1941. - No. 13. - P. 303 - 307

7.Shershenevich G. F. Textbook of commercial law (according to the edition of 1914). M., 1994. P. 110.

8.Karaseva M. Formation of corporations in Russia // Marketing. 2015. № 2.

9.Klimov A. P. Cooperation in the system of developed socialism. M., 1980. P. 485.

10. Chesterman S. Lawyers, Guns, and Money: The Governance of Business // Chicago Journal of International Law. - 2010-2011. - p. 321327.

11. Steven R.R. Corporations and Human Rights: A Theory of Legal Responsibility // The Yale Law Journal, 2001. - № 3- P. 452-540.

12. Valeev D. Kh., Golubtzov V.G. Modernization of the Russian law: a review of the laws on enforcement proceedings. - Life Science Journal 2014; 11 (8s); (ISSN: 1097 - 8135) - P. 234-238. 